\title{
THE APLICATION OF ROLE PLAY METHOD TO INCREASE PARTICIPATION OF STUDENTS IN LEARNING MANAGEMENT OF MIDWIFERY AT DIPLOMA-III OF MIDWIFERY STUDENTS
}

\author{
Gita Kostania, Kuswati, dan Firly Ratnawati \\ Program Kebidanan Politeknik Kesehatan Surakarta \\ email: oshigita@gmail.com
}

\begin{abstract}
In order to improve the achievement of learning objectives, we need a method of learning which can encourage the participation of students. Role play is a learning method that can increase student participation. The aims of this study is to determine the increase of student's participation in learning midwifery management using role-play method. Type of this research is a classroom action research, consisting of two cycles with phases: planning, implementation, observation, and reflection. There was an increase in student participation, judged by an increase in the percentage of each indicator, including student attendance for the planning of the first cycle to the second cycle of (25\%), where as the planning, implementation and process of discussion (10\%). In the process of implementation of role-play consists of planning and implementation, increased participation from the first cycle to the second cycle, the average amount (35\%). Furthermore, motivation of the students, also increased from the first cycle to the second cycle, with an average of each indicator by $(15 \%)$.
\end{abstract}

Keyword: role play method, participation, midwifery students

\section{PENERAPAN METODE ROLE PLAY UNTUK MENINGKATKAN PARTISIPASI MAHASISWA DALAM PEMBELAJARAN MANAJEMEN KEBIDANAN PADA MAHASISWA DIII KEBIDANAN}

\begin{abstract}
Abstrak: Tujuan penelitian ini adalah untuk mengetahui peningkatan partisipasi mahasiswa pada pembelajaran manajemen kebidanan dengan menggunakan metode role play. Jenis penelitian ini merupakan penelitian tindakan kelas yang terdiri atas dua siklus dengan tahapan perencanaan, pelaksanaan, observasi, dan refleksi. Terdapat peningkatan partisipasi mahasiswa terhadap indikator kehadiran serta pelaksanaan dan diskusi. Proses pelaksanaan role play untuk masalah aktual yang berkaitan dengan mahasiswa, masalah problematik, dan pemecahan masalah terdapat peningkatan tajam (100\%), juga sarana dan prasarana. Peningkatan dari siklus I ke siklus II juga meliputi persiapan naskah cerita, kecocokan pemeran efektivitas perilaku, penghayatan, dan pemeranan sesuai dialog. Selain itu, peningkatan juga terlihat pada hasil usaha untuk motivasi mahasiswa agar lebih memperhatikan, mencatat hal-hal penting, dan mau mengemukakan pendapat. Di pihak lain, mahasiswa yang hanya melamun dan sibuk sendiri mengalami penurunan.
\end{abstract}

Kata Kunci: metode role play, partisipasi, manajemen kebidanan

\section{INTRODUCTION}

Education is a conscious and deliberate effort to create an atmosphere of learning and the learning process so that learners are actively developing the potential for them to have the spiritual strength, self-control, personality, intelligence, noble character, and skills needed by the society, nation and state (UU RI No. 20 Tahun 2003, National Education System).

Understanding the concept of midwifery is the main asset of a midwife, and prospective midwives need to be controlled because the public demand for health care is on the rise, particularly the quality of midwifery care. One of the subjects in the study program of Diploma-III Midwifery is a midwifery concept that discusses midwifery management. In this case, midwifery students do the learning so they could understand the material easily.

Participation is the encouragement of students to develop thinking to achieve the learning objectives. For learning purposes, a method that can increase participation is needed. One of the methods is role play. In traditional methods, 
the students just listen to the lecturers' explanation so that sometimes students feel bored easily. One of the things that can influence it is the lack of motivation. Motivation is what can drive someone to do all the activities as well as to learn. When lecturers use interesting methods, students will not feel bored in their learning process.
One of the methods that can be applied is the role play because there are some advantages of this method. This method provides students with real situations, develops their creativity, cultivates the courage, enriches knowledge, and improves students' learning passion (Majid, 2013; Sukidjo, 2014).

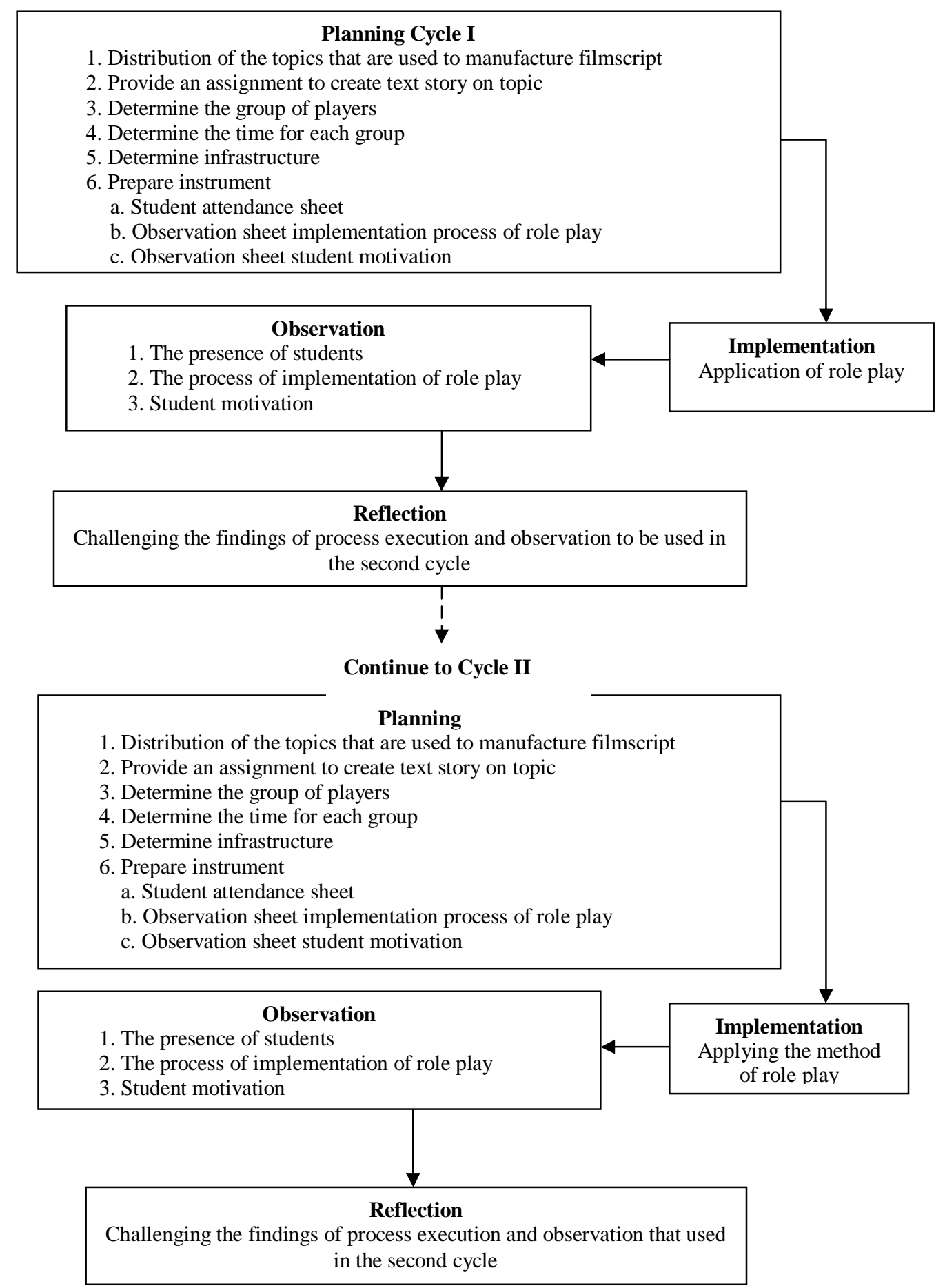

Figure 1. Procedure of the Research 
This study was aimed to increase students participation in learning midwifery management with role-play method.

\section{METHODS}

This research is classroom action research carried out in two cycles. The first cycle consists of: planning, action, observation, and reflection, while the second cycle consists of: a revised plan, action, observation and reflection. It can last for more than two cycles to achieve the intended learning objectives (Arikunto, 2009).

The first cycle is also used for improving the action done in the second cycle. The procedure in this study consists of four stages: planning, implementation, observation, and reflection. The procedures of the study can be seen in the Figure 1.

The data collected were quantitative in nature. The data were the result of the observation including the students' attendance, the implementation of the role play, and the students' motivation. The subjects were the first semester students, Diploma III of Midwifery Program, Health Polytechnic of Surakarta in 2014. There were 20 students involved as the subjects taken by cluster and quota sampling.

The students were divided into groups of five. Each group was then encouraged to choose a topic for a discussion. The topics which the students could choose were: menarche, primary amenorrhea, secondary amenorrhea, imperforate hymen, fibro adenoma mammary, anemia, flour albous, and dysmenorrhea. They should choose one topic and create a story based on the topic. Then, they should perform the story for about 25 minutes.

The instruments used in the study is the observation sheet, including: the students' attendance, the implementation of the role play, and the student motivation.

\section{FINDINGS AND DISCUSSION}

\section{Findings of the study}

This research was done in two cycles, Cycle I and Cycle II. The first step done was developing the syllabus. And then, the researcher prepared the task sheet that had to be prepared by the students in the learning process in the class. Student participation in the learning process can be assessed by using the following indicators: the students' attendance, the process of implementation of the role play, and the student motivation. The following is the result in Cycle I and Cycle II.

\section{Table 1. Students' Attendance}

\begin{tabular}{lcc}
\hline \multirow{2}{*}{\multicolumn{1}{c}{ Step }} & \multicolumn{2}{c}{ Percentage $(\%)$} \\
\cline { 2 - 3 } & Cycle 1 & Cycle 2 \\
\hline Planning & 75 & 100 \\
Implementation & 80 & 90 \\
Discussion & 80 & 90 \\
\hline
\end{tabular}

From the table it can be seen that there was an increase in the students' attendance from the first cycle to the second cycle. In the process of planning (25\%), and in the process of implementation and discussion (10\%).

\section{Table 2. Implementation of Role Play}

\begin{tabular}{|c|c|c|}
\hline \multirow[t]{2}{*}{ Step } & \multicolumn{2}{|c|}{ Percentage (\%) } \\
\hline & Cycle 1 & Cycle 2 \\
\hline Planning & & \\
\hline Actual problems & 100 & 100 \\
\hline $\begin{array}{l}\text { Problems associated with } \\
\text { student }\end{array}$ & 100 & 100 \\
\hline $\begin{array}{l}\text { Problems and problems } \\
\text { solving }\end{array}$ & 100 & 100 \\
\hline Preparation of script & 75 & 100 \\
\hline Infrastructure & 40 & 90 \\
\hline Implementation & & \\
\hline Compatibility cast & 40 & 90 \\
\hline Effectiveness of behavior & 65 & 90 \\
\hline Appreciation & 55 & 90 \\
\hline $\begin{array}{l}\text { Plays according to } \\
\text { dialogue }\end{array}$ & 60 & 90 \\
\hline Suitability of time & 100 & 100 \\
\hline
\end{tabular}

Based on Table 2 above, it is known that in the process of implementation in the classroom for the planning stages, the students' participation increased from the first cycle to the second cycle. These indicators include: actual 
problem, the problem is related to the student, problematic problems and problem solving, preparation of the story manuscript, and infrastructure. For the indicators of actual problems -- problems related to the student --, the problem was problematic and there was a solution. This is because in the first cycle, all students did well. In the preparation of the manuscript, the indicator increased by $25 \%$, and the infrastructure prepared students increased by $50 \%$. Furthermore, the stage of implementation consists of the following indicators: the suitability of the cast, the effectiveness of the behavior, appreciation, the acting based on the dia$\log$, and timelines. The indicator of suitability of the cast increased by $50 \%$ from the first cycle to the second cycle. The effectiveness of behavior increased by $25 \%$, the appreciation of the role increased by $35 \%$, the acting based on the dialog increased by $30 \%$, but there was no increase in the timelines indicator. This is because from the first cycle, the students did well.

\section{Table 3. Student Motivation}

\begin{tabular}{lcc}
\hline \multicolumn{1}{c}{ Indicator } & \multicolumn{2}{c}{ Percentage (\%) } \\
\cline { 2 - 3 } & Cycle 1 & Cycle 2 \\
\hline $\begin{array}{l}\text { Students pay attention during the } \\
\text { learning }\end{array}$ & 75 & 100 \\
$\begin{array}{l}\text { Students recorded during the } \\
\text { learning process }\end{array}$ & 80 & 100 \\
$\begin{array}{l}\text { Students argued in the learning } \\
\text { process }\end{array}$ & 10 & 30 \\
$\begin{array}{l}\text { Students daydreamed during the } \\
\text { learning process }\end{array}$ & 10 & 0 \\
$\begin{array}{l}\text { Students were sleepy during the } \\
\text { learning process }\end{array}$ & 0 & 0 \\
$\begin{array}{l}\text { Students interfered with friends } \\
\text { during the learning process }\end{array}$ & 0 & 0 \\
$\begin{array}{l}\text { Students were busy during the } \\
\text { learning process }\end{array}$ & 10 & 0 \\
\hline
\end{tabular}

Based on Table 3 it can be inferred that the two learning cycles using role-play models, there was an increase of $25 \%$ for students' attention during the learning process. There was also an increase of $20 \%$ in the students doing the recording during the learning process. An increase of $20 \%$ was found in the students arguing during the learning process. The percen- tage of the students who daydreamed decreased from the first cycle to the second cycle by $10 \%$. No student was sleepy and no student disturbed their friends. In the first cycle, $10 \%$ of the students were busy with themselves while in the second cycle there were no students who were busy with themselves.

\section{Discussion}

Suryosubroto (2009) said that participation can be measured by the level of attendance at the meeting, the learning process, and motivation. After the implementation of the role play method, there was an increase in the students' participation. This might be because the role play method is an interesting method so that there was conducive environment and finally the students could learn well. This is supported by a previous study by Kardoyo (2008) with the result of the increased participation of students in the subject matter of social science i.e. economics after the application of the role play method. Before the action, the percentage of the participation was $51.16 \%$, and in the first cycle it increased to $74.42 \%$, and in the second cycle it increased to $86.05 \%$.

The presence of students in the planning process has also increased from Cycle I to $\mathrm{Cy}$ cle II. No student was late to class on the second cycle. According to the Academic Regulations of Midwifery Program, Health Polytechnic of Surakarta (2013) on student attendance, students are expected to come to class at least 5 minutes before the lecture takes place. Suryosubroto (2009; Rohaeti et.al, 2013; Hong \& Lawrence, 2011) explain that the level of presence in learning is one way to measure student participation. Participation is an effort for some one to participate in an activity. With the presence of students in the classroom, it can be concluded that they have participated actively in the lecture.

Another increase was also found in the role play of the implementation process from Cycle I to Cycle II. Before the process of implementation of the role play, the researchers prepared the topics that would be distributed to students including midwifery care at menarche, 
primary amenorrhea, secondary amenorrhea, imperforate hymen, fibro adenomas mammary, anemia, flour albus, and dysmenorrhoea. Then the researchers provided job descriptions to be done by the students, that is, a scenario based on the topics that have been given, by showing midwifery management measures. Then the researchers divided the students into 4 groups consisting of 5 members each. After the implementation of the method of the role play in two cycles, it can be concluded that there was an increase in the stages of planning and implementation. The increase was due to the increasing participation of the students. The students were enthusiastic in attending the lecture. Majid (2013) said that the role play method has advantages. The role play method can be used as a basis for the students to face the actual situation. It can also enhance self-confidence.

Motivation to learn is internal and external encouragement to students who are learning to make changes in their behavior (Hamzah, 2012). The data showed that the students' motivation increased after the implementation of the role play method in two cycles. The increase of the motivation could be seen from the following indicators: students' attention and their willingness to take notes during the implementation of the role play method. They could also mention the midwifery management measures correctly. Hamzah (2012) explains that student motivation can be improved through the implementation of the role play method in the learning process. This is because the role play method is an interesting learning process for students. This causes learning to be more meaningful for students. In line with the theory put forward by Sardiman (2012), motivation can encourage students to do something and to determine the direction of action to be achieved. These include: students' attention, willingness to take notes, drowsiness, and interference. The role play method is an external drive that can be created by an educator to be able to increase students' participation.

Increasing participation achieved in each cycle shows that the action taken affect on the increase of the students' participation in each indicator concerned. Thus, the increase in parti- cipation occurs because of the application of the role play method. The role play method can increase students' attendance and the students take an active role in the learning process.

\section{CONCLUSION AND RECOMMENDA- TION \\ Conclusion}

This study was conducted in two cycles. In each cycle, the researcher observed the students' attendance. The stages in each cycle are planning, implementing, and evaluating. The researcher also observed the implementation of the role play method and the students' motivation in joining the learning process. Through the implementation of the role play method, the students can foster higher motivation and this increased the students' participation. This can be seen from the increase of each indicator from the first cycle to the second cycle.

Based on this study, it can be concluded that the application of the role play method can increase students' participation in the learning process. The application of the role play method gives an emphasis on the active involvement of students in the learning process. If the active role of students increases, the learning motivation will also increase, so as to improve student learning achievement.

\section{Recommendation}

One of the strategies that can increase students' participation is by application of the method role play. This learning method can be implemented as a variation in learning. The application of the role play method can also motivate students to be more active in learning, so the students will feel delightful and they are not bored. The role play method can be implemented in other subjects which requires more indepth understanding.

From the above explanation, it can be described below.

Fisrt, educators should use an active approach in implementing learning in the classroom, with students made closer to the real situation, so that their understanding will in- 
crease. The application of the role play method is believed to be effective and helpful.

Second, To increase students' participation, educators should prepare job descriptions carefully, ranging from setting goals, analyzing the material, drawing up the operational measures, and designing the evaluation, with the emphasis on the element which gives great opportunity for students to learn actively.

Third, In order to improve the quality of graduates, it is necessary to improve the quality of learning on an ongoing basis by those responsible. One of the ways is by conducting action research on the learning process in the classroom.

\section{ACKNOWLEDGEMENT}

The authors would like to express their gratitude to all those who have helped and supported the research and the preparation of this research article. The author would like to thank to Ministry of Health-Polytechnic Health of Surakarta, especially Director and Chairman of the Department of Midwifery who have provided guidance and support for the implementation of this research. The authors are also grateful to the editorial board and staff Cakrawala Pendidikan who have published this article.

\section{REFERENCES}

Arikunto S. 2012. Penelitian Tindakan Kelas. PT. Jakarta: Bumi Aksara.

Hong, C.E, Lawrence, S.A. 2011. "Action Research in Teacher Education: Classroom Inquiry, Reflection, and Data-Driven Decision Making". Journal of Inquiry and Action in Education, ed.4(2), p.1-17.

Majid, A. 2013. Strategi Pembelajaran. Bandung: PT Remaja Rosdakarya.

Rohaeti, E, Suwardi, Ikhsan J. 2013. "Penerapan Siklus Belajar 5E Disertai LKS untuk Peningkatan Kualitas Proses dan Hasil Belajar". Cakrawala Pendidikan, Th.XXXII, No.2, hal.315-325.

Sardiman. 2012. Interaksi dan Motivasi Belajar Mengajar. Jakarta: PT Raja Grasindo Persada.

Suryosubroto, B. 2009. Proses Belajar Mengajar di Sekolah. Jakarta: PT Rineka Cipta.

Sukidjo. 2014. "Kompetensi Penelitian Tindakan Kelas Guru SMP DIY". Cakrawala Pendidikan, Tahun XXXII, No. 3, hal. 368-378. 